\title{
Depictions of Laestadianism 1850-1950
}

\author{
DOI: https://doi.org/10.30664/ar.87789
}

(ㅇ)(1)

Attribution 4.0 International (CC BY 4.0)

$\mathrm{T}$ he issue to be discussed here is how society's views of the Laestadian revival has changed over the course of the revival movement's first 100 years. The article claims that society's emerging view of the revival is characterized by two different positions. The first period is typical of the last part of the nineteenth century and is characterized by the fact that the evaluation of the revival took as its point of departure the instigator of the revival, Lars Levi Laestadius (1800-61). The characteristic of Laestadius himself would, it was thought, be characteristic of the movement he had instigated. During this first period, the revival was sharply criticized. This negative attitude gradually changed from the turn of the century onwards. The second period is characterized by greater openness towards understanding the revival on its own premises. This openness showed itself at first in Swedish publications that treated the revival in an exotic fashion with the aim to arouse greater interest in the Swedish cultural life in the north. This interest in the distinctive qualities of the revival was later also expressed in Norway, thus contributing to a change of view in how society viewed Laestadianism. Typical of the second period is that it was primarily in the ecclesiastical environment that a new interest in the revival established itself.

The ISSUe TO BE DISCUSSED in this article is how the public view of the Laestadian revival changed during the revival's first 100 years (1850-1950). Although we shall primarily focus on the Norwegian context, we cannot limit ourselves strictly to this country. Until 1905, Norway was united with Sweden, and so what happened in Sweden was also important for Norway. This was even the case for a fairly long time after 1905, especially with regard to a religious movement that united people from three Nordic countries (Sweden, Finland and Norway).

The Laestadian revival originated in northern Sweden during the late 1840 , and was led by the parish minister of Karesuando, Lars Levi Læstadius (1800-61). Within a few years, the revival spread to the neighbouring countries Finland and Norway. In Norway, most parishes were affected, from Ofoten in the south, to Varanger in the north-east. During the first two decades, the revival spread mostly among the Sami and Kven minority groups. Norwegians tended to view the revival in terms of ethnic characteristics, often using derogatory labels to convey their views (i.e., Finnetusse, 'Sami madness' or Kventrua, 'Kven faith'). Such labels can be understood in terms of what anthropologists call 'othering' which are understood as attempts to create boundaries that distinguish 'ingroups' from 'outgroups' (see Barth 1969).

The views about Laestadianism discussed in this article focus on public texts, 
distributed and read mainly by an audience outside the Laestadian movement. The study is limited to the early phase of Laestadianism, that is, prior to the time when academic studies began to develop. Cultural essentialism is typical of this early phase. Such essentialism is based on the idea that people have inherent characteristics that do not change because they are perceived as being 'natural' (see ShurmerSmith 2001: 57).

An important change in the study of Laestadianism took place in the midtwentieth century as the first doctoral theses dealing with the Laestadian movement were published. This change contributed to a change in the common view of Laestadianism. ${ }^{1}$ The new perspectives were partly derived from church history, and focused on detailed studies of available source material for how the revival began and developed. At the same time, new questions and perspectives were beginning to emerge from the social sciences. Such views were often based on functionalist theories about how religion works depending on their social and cultural contexts. We shall not deal with this development in this article.

The major findings of this study are that society's emerging view of the revival is characterized by two different positions. During the first period (1850-1900) the evaluation of the revival focused on the instigator of the revival, Lars Levi Laestadius, and interpreted the characteristics of the revival based on perceived personal shortcomings of Laestadius himself. What was typical of Laestadius, it was

1 At first in Finland by the works of Aulis Zidbäck (1937) and Martti E. Miettinen (1942), then later on in Sweden by Per Boreman (1953 [1954]) and in Norway by Dagmar Sivertsen (1955). thought, would have been transferred to the movement that he started and continued to lead until his death. During the latter part of the nineteenth century, most commentators were highly critical of the movement, partly due to 'the Kautokeino event of $1852{ }^{2}$. From the turn of the twentieth century, however, this negative view gradually changed, and during the second period (1900-50), the views of Laestadianism were replaced with what we might call an 'exoticizing phase', characterized by an increased interest in and openness towards the revival as a phenomenon of the religious and cultural north. This article suggests that the openness first developed in Sweden, but was soon introduced and continued also in Norway.

\section{Period 1 (1850-1900):}

\section{Laestadianism as deviation}

Health-related criticism:

\section{Laestadianism as a spiritual infectious disease}

The first period came to be strongly influenced by the events in Kautokeino of 1852, when a local merchant and the sheriff were killed. These events left a deep impression on the first person to write about the uprising: Fredrik W. Hvoslef (1825-1906), the parish priest of Kautokeino, who had been present and had been a target of the rebels' rage. At the request of his bishop, Daniel Juell, Hvoslef wrote an article on the event (Hvoslef 1857). This account contributed to a widespread negative view of the revival.

The issue of Laestadian followers as a group was only indirectly tackled by Hvoslef in the article, but he got to grips with the theme in depicting how a group of

2 I choose the word 'event' as neutral term. Other words (such as uprising, riot, revolt or tragedy) have also often been used, signalling particular views of the event, cf. Andresen 2007: 130. 


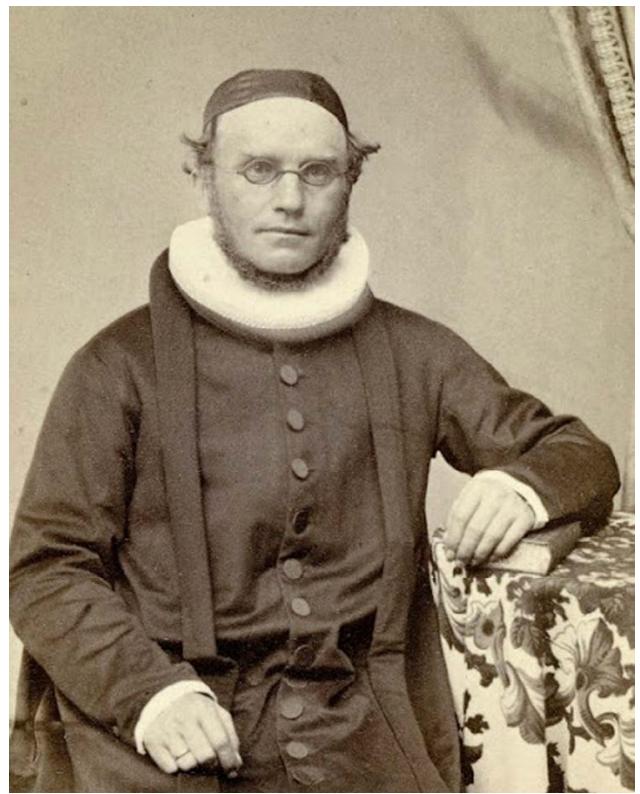

Priest and Bishop Fredrik Waldemar Hvoslef (1825-1906). Claus Knudsen / The National Archives.

preachers came to Kautokeino in the winter of 1847 and presented themselves as emissaries from Laestadius. Hvoslef describes how the preachers worked on the audience's conversion, 'playing on their consciences, by remonstrating with them for the Shameful and Ungodly way they had previously led their Lives in Drunkenness, Thievery and Fornication' (Hvoslef 1857: 9). After exerting themselves in this way for a while, the preachers returned to Karesuando, but came back again the following year. On this occasion they changed their method. Whereas their proclamations during their first visit were a radical exhortation to repent, during the second visit the focus was on the proclamation of holiness. With this change there emerged a sharper distinction between those who were born again and those who had only been awakened. The change was expressed by the fact that whereas the preachers during their first visit had emphasized the inner life of the soul, the focus of their second visit was on the revival's forms of expression. This model had been borrowed from Karesuando, where sorrow 'was uttered by the Cry and the Sigh or the Groan, and Joy by Laughter and Dancing or by Jumping and Leaping' (p. 12). Hvoslef asserted that the source of the revival in Kautokeino was inspired by Laestadius himself, but his criticism was also based on the Sami people's 'obstinate spirit' (p. 3). After the emissaries from Karesuando left Kautokeino, the radicals took over the leadership and pursued it with obvious and scandalous excesses.

Hvoslef concluded his article by reflecting on the progress of the revival in Karesuando, even though his knowledge of the revival there was fragmentary (Hvoslef 1857: 30-7). He maintained that Laestadius's theology put too much emphasis on people's inner feelings, so that they were willing to use every possible means to evoke them (p. 32). Hvoslef was also critical of Laestadius's defence of believers' visions that were to be understood as subjective religious truths. Hvoslef believed that such a view paved the way for precisely the type of spirituality advocated by the radical group in Kautokeino.

Despite the critical remarks concerning the theology of Laestadius, it nonetheless seems that Hvoslef judged the revival in Karesuando in positive terms. He considered the tragedy in Kautokeino to be partly a consequence of a lack of theological guidance by parish priests, and partly the result of the Sami people's self-reliant nature and their tendency to exaggerate their sense of the spiritual. It is probably this final emphasis on the character of the Sami that later led him, as Bishop of Tromsø, to criticize the progress of Laestadian followers in his diocese. In the bishop's copybook for 1871 , he wrote that for many years there had been an 'eccentric religious movement', primarily among the Sami in the parishes of Ibestad 
and Ofoten, and the revival had now propagated itself among the Norwegians, resulting in unpleasant incidents both in and outside the church.

Laestadianism was flourishing on the Norwegian side and this led Hvoslef to seek more information. He probably envisaged the possibility of another Kautokeino uprising and wanted to take necessary steps to forestall such an event. In 1871 , he asked the incumbent parish priest in Kautokeino, Ole A. Johannessen (1829-1913), to visit places where the movement was having the strongest effect, that is, in the farming villages in southern Troms and northern Nordland. His report was largely positive and did not overstate matters, which probably helped to set the bishop's mind at rest. In his report to the ministry dated 19 March 1873, he states that the religious movement had assumed quieter forms, though it was not declining. The Laestadians' jumping and leaping about in the church during communion did not happen as often as before, but the movement was growing stronger among the Norwegian population, especially among the women. Some clergymen interpreted Laestadian spirituality among the women as a cover for their sickly, nervous and hysterical behaviour. ${ }^{3}$

In commenting upon this, Hvoslef (1857:12) says that it was among the women that the revival made the greatest progress. It was also usually the women who caused disturbances during church worship with their heartfelt expressions of joy or sorrow. Like many of his contemporaries, Hvoslef

3 A clergyman who voiced such ideas in a letter to the Tromsø bishop, was the ambulatory chaplain, Anton Chr. Hall (18411911). His letter is in The State Archives in Tromsø, Bishops' archive. The visitation protocols in the Bishops' archive contain many other examples of emphasizing the women's role in the awakening. considered such expressions of religious emotions as a form of hysteria that had some form of bodily sickness as its basis.

This emphasis on perceiving the religious revivals in Kautokeino from a sickness perspective was also shared by the medical doctor, Ludvig Dahl (1826-90), who was a pioneer in the scientific study of mental illnesses in Norway. In the late 1850s, the government assigned Dahl the task of investigating the occurrences and causes of mental illness in Norway (see Dahl 1859). Mental illness was at the time considered an important medical problem, and Dahl's findings contributed to a new understanding of mental illnesses in a time in which 'madness' was increasingly becoming subject to medical treatment. ${ }^{4}$

In Dahl's research, he became aware of a possible connection between religion and mental illness. This connection led him to interpret religious revivals from a medical perspective. In 1862, Dahl wrote an article that was published in two editions of Folkevennen (The people's friend) magazine. In his article, Dahl portrayed 'madness' as an abnormal deviation that could be described and hopefully treated by medical science. By presenting mental illnesses within the context of normal and abnormal, Dahl's view harmonizes well with that put forward by Hvoslef in his 1857 article in which he interpreted the madness of the Kautokeino rebels as a religious deviation from ecclesiastical norms.

4 See the historical analysis of Dahl's medical views on mental illnesses in Grene and Lie 2018. Contributing to the question of mental illness in connection with the Kautokeino 1852 event, the Mental Illness Act of 1848 had established a general exemption for 'maniacs' from punishment (Andresen 2007: 131). 
Ludvig Dahl's perceptions carried considerable weight at that time. Following his medical exams in 1851, he travelled abroad to study institutions for the mentally sick and focused on this group of patients throughout his career. In 1862, he established a mental asylum in Trondheim and was in charge of the asylum until 1864 when he was appointed as an administrator to the medical office of the Ministry of the Interior. In 1875, he was elected as the national Director of Medicine and continued in this post until his death. His published works exemplify early empirical research texts in the field of Norwegian psychiatry.

Dahl's research view needs to be understood in the context of his views on religion. For Dahl, Christianity and the Church were a given part of his life-view and he did not direct any criticisms against religion itself. At the same time he belonged, by virtue of his education, to the higher class of officials who were critical of the type of religiosity that expressed itself on the outer edges of the state church. The ordinance governing religious assemblies was repealed in Norway in 1842, and legislation concerning dissent was passed three years later. Dahl was critical of many of the religious expressions this paved the way for, and in his article in Folkevennen he drew attention to the northernmost parts of the country and the 'sickly expressions of life' that had arisen under religious revivals (Dahl 1862: 1). He gets started with observations critical of Laestadianism and perceives its religious dynamics in the light of similar phenomena elsewhere. He believed that a common feature of such expressions is that they can be classified as 'sickly'; compare with the article's headline, 'Om nogle aandelige Omgangssygdomme' (On some mental infectious diseases).

Dahl's primary sources were the medical

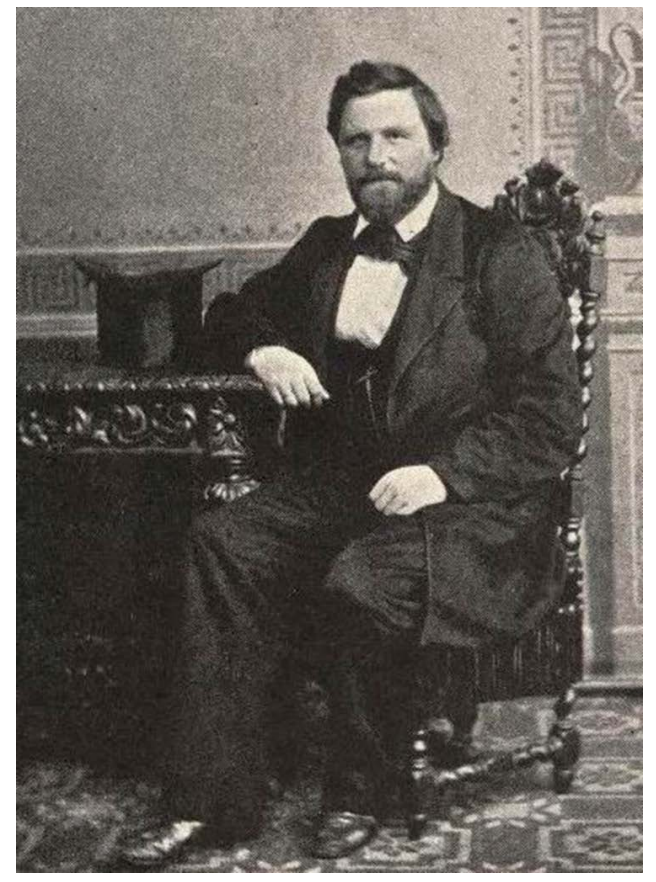

Medical doctor Ludvig Wilhelm Dahl (18361890). University of Oslo anniversary book Det Kongelige Fredriks universitet 1811-1911 (published in 1911).

records of district physicians, but in 1858 he also had the opportunity to witness for himself religious revivals in the north. His first example was taken from a report by a district physician in Tranøy, Andreas Berbom (1822-6o), who in 1858 wrote that in the far north he had found a form of sickness he had previously seen only in southern lands. The sickness manifested itself in convulsions arising from religious influence, especially among women. The convulsions were often of a hysterical nature, although their strength varied. Berbom states that itinerant preachers were adept at making use of people's overwrought emotional lives, so that when one person was brought to ecstasy, others soon followed (Dahl 1862: 4).

Berbom's focus on the religious revivals in the parish of Tranøy may have been influenced by the case of Cathrine 
Pedersdatter (1814-63). She was a Sami woman, born in Jukkasjärvi, but who lived at Reinsmoen in Sørreisa. During the early 1850s, she became known for her visions of the destiny of individuals' eternal souls. These visions were written down and published by, amongst others, the Member of Parliament Peder Andersen, a Haugian ${ }^{5}$ from Bardu in Troms county. This leaflet aroused interest and was published in several editions. Rumours about Cathrine also reached Bishop Juell in Tromsø, who asked the Tranøy priest Carl Theodor Schmidt (1810-92) to investigate the matter. Cathrine told the priest that twice she had visions in which she was told to exhort people to turn away from sin and live a spiritual life (Hanssen 1994: 217-19). She explained that in her visions she had been shown heaven and hell, and had set named individuals on the path to one place or the other. The priest told Cathrine that as a woman she was not allowed to preach the Word of God, and that she should take care not to lead others astray with delusions she perceived as true.

The visions experienced by Cathrine were well-known in the early years of Laestadianism and, given her background from Jukkasjärvi, it is likely that she had been influenced by Laestadianism. It is also likely that Karen Nirpi from Gratangen experienced similar visions following her conversion in Jukkasjärvi in 1847. Following her return to Norway in the spring of 1848 , her words were the source of great revivals in the parishes of southern Troms (Kristiansen 2004). Similar revivals occurred in many other places, especially at the hands of itinerant preachers from

5 Haugian: an adherent of the revival movement in the early nineteenth century, instigated and led by the lay preacher, Hans Nielsen Hauge (1771-1824).
Sweden and Finland. The revivals were discussed by other district physicians, for example Christoffer A. Schjelderup (181587 ) in Trondenes. Dahl cites in detail from this doctor's report.

Dahl (1859: 1) believed that the Laestadian revivals were of a similar nature as revivals elsewhere, and that they were often accompanied by ecstatic phenomena such as revelations, visions, convulsions and swooning. According to him, these were the result of overwrought and fanatical feelings. He was particularly concerned with revival expressions in the form of 'agitations' (rørelser), which manifested themselves both spiritually and physically. Dahl's main perspective was the pathological: how a weakened mind could be overpowered by religious notions to such an extent that they could not distinguish between internal and external reality. One's inner spiritual world would seem real and actual, something that could easily lead to fanaticism tipping over into acute mental illness.

Dahl was careful about stating whether there was a direct connection between Laestadian revivals and mental illness. He was well aware that religious revivals occurred all over the country, though he stated that 'to such an Extent ... that these fanatical Movements have reached the northernmost Regions in the Land, I do not know whether they have ever done so elsewhere in the Land' (Dahl 1859: 15). He believed that the reason for this was that 'the long Darkness itself is well suited to arouse and sustain this Fanaticism' (p. 7). In order to understand the revival's fanatical fervour, Dahl turned to Laestadius's own words in his journal Ens ropandes röst (One's calling voice, Laestadius 1979). Dahl was interested in this report because it showed how Laestadius 'became a Fanatic and how he came to spread Fanaticism among the Lapps' (Dahl 1859: 18). Dahl 
quotes from Laestadius's autobiography, which he believed showed that from his youth onwards, Laestadius was gripped by a spiritual confusion that helped to cause his inability to distinguish between internal and external reality.

Ludvig Dahl's research perspective is clearly based on his identity as a doctor, for whom religion had its place in his life as an organizing factor. Religion was supposed to contribute to offering people a rounded view of reality and to convey central values and norms for human life in society. Revivals, on the other hand, Dahl perceived as something that caused disorder. The revivals thus became a source of disorder in society and were to be regarded as a threat to the prevailing social order. The solution was to treat the extreme forms of revivalist religion as deviations from normal behaviour in one of sound mind.

\section{Theological criticism: a spiritual form of materialism}

Jacob A. Englund (1831-1914) was the first of the theologians of the Church to publish a study of Lars Levi Laestadius and his theology (Englund 1876). In his 160page article he set out to study the theological peculiarities of the revival and was probably one of the first in a scholarly context to refer to Laestadius's followers as 'Laestadians'. Other expressions were also used in Englund's time to designate the revival. Jakob Ahrenberg (1897) in Finland, for example, called the Laestadian followers hihulittes, ${ }^{6}$ whereas

6 The word has a connection with the sounds ('hi-hu') that emerge when the awoken reach ecstasy, cf. Ahrenberg 1897. Englund (1876: 156) also refers to 'hihu-believers' and asserts that the group had a particular connection with the northern part of Österbotten, such as Ijo (Ii) and Lillkyro (Vähäkyrö). the believers referred to themselves as 'snabbtroende' (literally, believing rapidly or hastily).

Englund calls his study an impartial portrayal' and begins by describing the revival as being 'lost in dogmatic determination and drifting between different doctrines, as obscure as their religious views', concluding - like Dahl - that such a revival cannot exert 'a healthy influence on their character' (Englund 1876). Another similarity with Dahl is Englund's focus on the originator of the revival. Both use the depiction of Laestadius's life as key to understanding the peculiarities of the revival; in Dahl's case, to understand the revival's ecstatic expressions, and in Englund's to understand its theology. It is the dogmatic interest that is the focus in Englund's work. As far as the revival's forms of expression are concerned, he is content to point out how they disturb church services, referring to the fact that secular authorities on several occasions had to intervene against such disturbances.

Englund perceives the growth of the Laestadian revival against a background of 'the sad state of affairs in Karasuando parish, noting that even the settled population was 'poor, no extraneous belongings, scattered here and there in the wilderness' (as quoted in Boreman 1954: 9). He is, however, more concerned with understanding how Laestadius's theology is expressed in the written sources available to him. On the basis of his source material he concludes that both Laestadius himself and his followers were characterized by a 'defective harmony' (Englund 1876: 121).

One important question that interested Englund was whether Laestadius should be regarded as an idealist or a materialist. He concluded that Laestadius should be regarded as a materialist because he perceived the life of the soul as a product of 
the material organism. ${ }^{7}$ Englund maintained that Laestadius tried to reconcile two different trains of thought that prevailed in his day, namely materialism and spiritualism, something which he believed Laestadius had failed to do.

According to Englund, Laestadius's anthropological views were at the heart of his philosophy. Englund was familiar with Laestadius's unpublished, handwritten work in five volumes, Dårhushionet (The lunatic, published in 1997). He calls the manuscript a 'Carnatic psychology', maintaining that it represents 'the most unbridled materialism in association with evangelical faith, a Christian and materialistic view of life all at once' (Englund 1876: 26f.). He shows how what is called the soul of Laestadius is understood exclusively as 'nerve life' and 'organ life'. The life of the soul is thus a result of physical human development. At the heart of Dårhushjonet is the theme of passions that dominate the human heart, which is the centre of life. Based on the passions of the heart, this influence flows out to other aspects of organic and nervous life. Laestadius gained support for his views from French and German anthropologists of his own time (the 1850s). For Englund, such a form of anthropology seemed alien a mere quarter of a century later, and he labels Laestadius's ideas as 'anthropological speculations', refusing to delve deeper into his philosophy. Instead, he came to the conclusion that if the passions had their basis in a material organ in the human body, and

7 Boreman (1954: 201) upbraids this statement and warns against looking at Laestadius's view of the relationship between body/soul and matter/spirit in a simplistic fashion. The topic is dealt with in depth by Laestadius in his Dårhushjonet writings, but Englund says he never studied these writings in depth. thus not subject to the will of man, then this must be a 'feathered prisoner of passion, and all talk of freedom comprises empty words as long as he [Laestadius] moves on the wavering ground of his not particularly thought-through or sharp-eyed speculation' (Englund 1881: 436). Instead, Englund provides an analysis of how central dogmatic themes were understood by Laestadius and his followers to show how these could be seen to deviate from a normative Lutheran theology. What was decisive for Englund, was to criticize what he perceived as errors of which Laestadius and his followers had been guilty.

When Englund wrote his article in 1876 , the Laestadian revival was in the process of being divided into two flanks, one extreme and one moderate. As an example of the extreme flank, he mentions a movement that he calls the huhtari sect in northern Finland that he claims has degenerated into a completely unrestrained hyper-evangelism. The moderates are represented by those priests of the church who had themselves joined the revival and who sought to make it more acceptable by toning down its more extreme characteristics. ${ }^{8}$

Englund's 1876 and 1881 texts remained for a long time standard works for theo-

8 One example of this approach was the writings of a group of priests who focused on the penitential practice of the Laestadians, which they asserted had broken with the Lutheran tradition (Hedlund 1889). Their writings built on an article written by Bishop Lars Landgren (1810-88) in Härnösand, in which he considered the Laestadian penitential doctrine and its 'deviations from the Evangelical Lutheran doctrine' (p. 3). Another Swedish bishop, Gustaf Johansson, published a book in 1892 on Laestadianism which depicted the revival's many faults. Part of the book was later released by the provost A. Nyman (Johansson 1898). 
logians' assessment of the Laestadian revival. His influence is noticeable well into the twentieth century, for example in the work of Paul Heurgren (1864-1928) who gave a lecture for the Concordia association in which he pictured Laestadius as a religious fanatic (Heurgren 1916). He worked for fifteen years as district veterinarian in Kalix in Norrbotten. Meeting Tornedalen's Laestadian followers sparked his curiosity concerning both the movement and its originator. He read Englund's work and whatever he could find of Laestadius's own writings, including copies of his sermons and his journal, Ens ropandes röst. Heurgren was highly critical of the Laestadians. He referred, for example, to revivalists as those who 'not always in a charitable way made their mark on the people's character up there' (p. 3).

Heurgren's view of Laestadius and Laestadians shows clear continuity with Englund's perspectives, even though he does not examine his theological analyses. Furthermore, many of Heurgren's points of view are strongly aligned with Ludvig Dahl's article. Like Dahl and Englund, Heurgren also takes Laestadius's life story as his point of departure in order to understand the form of religion that characterized his subsequent followers.

Heurgren labels Laestadius a doomsday prophet with a bitter hatred of the world, which Heurgren believed to be the result of the poverty-stricken surroundings and lack of harmony at home during Laestadius's childhood. The depiction of Laestadius as a person is entirely negative. Living conditions in Karesuando did little to appease Laestadius, but the source of his new 'spiritual spring' was the revival that occurred in Karesuando in 1845, which summoned him to entirely new and different tasks. He evolved to become a 'very sober fighter and a spiritual speaker' (Heurgren 1916: 8),

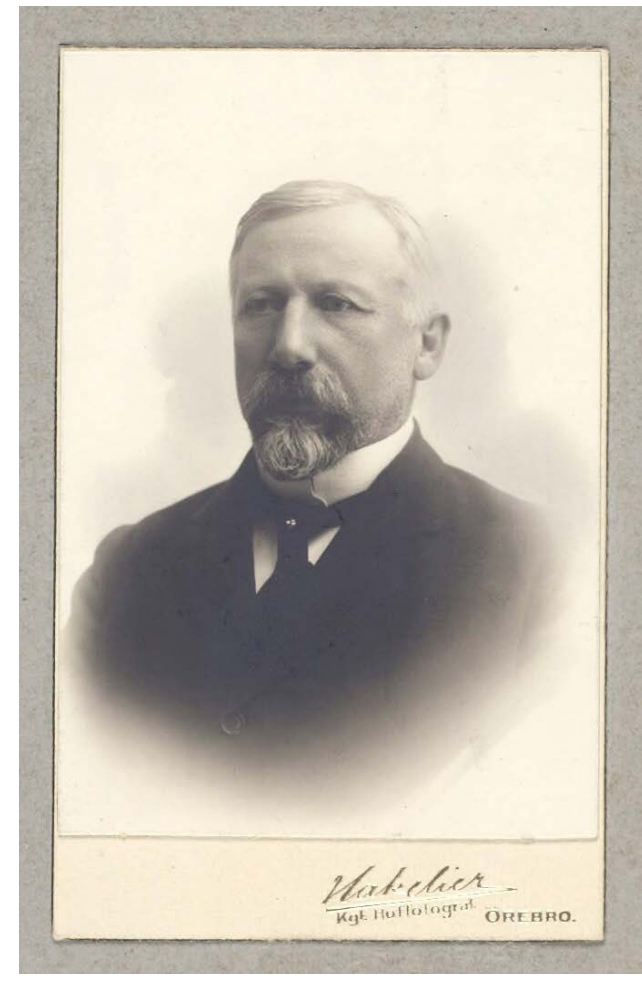

Paul Gustaf Eric Heurgren (1864-1928).

Det Kgl. Biblioteks picture collection.

beloved by his followers and hated by his opponents.

Heurgren tried to find the key to understanding not just Laestadius himself but also the revival he founded, by means of Laestadius's own life and writings. In line with this method he called attention to Laestadius's words against all forms of luxury and his contempt for the higher forms of doctrine that in Laestadius's time were increasingly influencing the Church. This new doctrine was for Laestadius just a false skin that served to cover an empty shell of spirituality. This view became crucial to Laestadius's contempt for the world, rationalizing why his followers would subsequently be characterized by the same ideals. Heurgren also flavoured his depiction of Laestadius with quotations from his sermons to reveal their coarse form - and to illustrate the fanatic doomsday prophet 
(according to Heurgren) that he became. The agitations that Heurgren claims such a type of proclamation gave rise to are described in words such as 'frenzy' and 'inferno', in which his listeners lost control of themselves, creating havoc. Heurgren places the events of 1852 in Kautokeino in this context, interpreting it as an expression of the logical consequences of an uncultivated and fanatical form of religiosity Laestadius had 'sown the wind and reaped the whirlwind' (Heurgren 1916: 16).

Heurgren's depiction of Laestadius and his preaching is dark. Laestadius is presented as a deviant in terms of both his manner and his preaching. Things were no better among Laestadius's followers, according to Heurgren. True, alcohol problems had lessened considerably as a consequence of the revival, and people's moral behaviour had considerably improved, but he doubted many of the claims that that things had improved because of Laestadius. Heurgren claimed, endorsing Englund, that Laestadian penitential preaching had also given rise to widespread hypocrisy (Heurgren 1916: 22), which concealed problems rather than solving them. Heurgren concluded that Laestadianism was like 'the trees that sprout haphazardly, sown by Laestadianism, which are shrunken and the wood lacks marrow: they shall endure with the colourless plants that are surrounded only by the dry, burning desert sand' (p. 25, author's translation).

Hvoslef, Dahl, Englund and Heurgren's works represent the four most significant contributions in the early assessments of Laestadianism. All three are characterized by a highly critical attitude towards both the revival and its originator, and they present the movement as a deviation from a given concept of the 'right' form of religiosity. This negative perspective was, however, soon to be challenged.

\section{Period 2 (1900-1950):}

\section{enlightenment and apologetics}

Shortly after the turn of the twentieth century, the first publications began to appear in which the sternly critical approach to Laestadianism was replaced by a more sympathetic perspective. Elisabeth Curtelius (1870-1942), who was related to Laestadius, ${ }^{9}$ published a book in 1908 about Lars Levi Laestadius's half-brother, the priest Carl-Erik, followed a year later by a book about his brother Petrus. In 1914, she published a book about Lars Levi himself, which was given the subtitle, 'a fighter for sobriety in the High North' (Curtelius 1914). ${ }^{10}$ In her introduction to the book, Curtelius writes that she wants to depict current trends in the development of Christian culture and raise the awareness of such currents among Christian youth in Sweden.

During the 1910s, several books were released by Svenska kyrkans diakonistyrelses bokförlag (Swedish Church Deaconry Board publishing company), with lively depictions of Laestadianism. In 1916, a book appeared called Ropande Röster $i$ Ödemarken (Voices calling in the wasteland) by the schoolteacher and priest Carl Edquist (1870-1948). ${ }^{11}$ In his book, Edquist described ecclesiastical life in Swedish Lapland. The following year, his wife Märta Edquist (18781960), who was also a teacher, published the novel Norrskensflammor (The flames

9 Curtelius's maternal grandfather was the son of Laestadius's half-brother, Carl-Erik Laestadius.

10 The book's Swedish subtitle was, 'en nykterhetskämpe i höga Norden'.

11 Carl Edquist was for a time the inspector of elementary schools for the county of Gävleborg, and later a parish priest in Kiruna (1913-20). 
of the northern lights), about Lars Levi Laestadius's life and works. Three years later, she wrote a story about 'the old church village', that is, Karesuando (Edquist 1921), where Laestadius had been a priest, and a year later she published a biographical account of Lars Levi Laestadius (Edquist 1922). Her books took a popular form and she probably adopted a light approach to research and source material. Per Boreman and Gustaf Dahlbäck (1965: 57) maintain that her books included halftruths and rumours that in many cases had been spread to harm Laestadius and his followers.

The Deaconry Board's books are mostly concerned with the work of the Church in northern Sweden, representing a form of ecclesiastical enlightenment that was meant to help make the Church's own people better informed about conditions in the far north. When Laestadianism is discussed, it is emphasized that the revival has a legitimate place in the Church and that it should not be perceived as alien or dangerous. Heurgren's disparaging portrayal of Laestadianism may have played a part in this choice of ecclesiastical publishing strategy. Literature was required that could reveal other aspects of Laestadianism than the many negative depictions which had dominated previously.

One very significant publication put out by the Deaconry Board was a contribution from Hjalmar Westeson (1885-1959). He served the Karesuando parish from 1915 to 1923. Based on a solid knowledge of the Laestadian narrative tradition, he published in 1922 a lively depiction of significant individuals among Laestadius's followers. The book became a classic account of the revival's pioneers, seen from the movement's own perspective. Westeson followed up these biographical accounts in the years that followed with other narrative material from Tornedalen, where he focused on the interaction between nature and northern Swedish culture.

The Deaconry Board's books were supplemented by several other publications, for example, a book by Valdemar Lindholm (1880-1947) about the brothers Lars Levi and Petrus Laestadius, published by Svenska Missionsförbundet (Swedish Mission Association; Lindholm 1937), as well as Ödemarkens apostel (The apostle of the wasteland), a book by Oscar Rönnbäck (1896-1935) in the Harrier publishing company's extensive 'Bragd och hjältedåd' (Achievement and heroism) book series (Rönnbäck 1945). In the foreword to Rönnbäck's book, it is mentioned that the principal aim of the book series was to present in popular form a broader perspective of individuals, movements and reforms in Swedish history. It was felt that more historical knowledge would increase understanding between different groups of people and thus reduce social conflicts in society.

The book series' publication by a commercial publishing company underlines the fact that Sweden's northern territories are important and that the religious history of these areas should be viewed as part of Swedish history in general. ${ }^{12}$ The publishing company admitted that, for many, Laestadius was a controversial person: 'some find Lars Levi Læstadius wonderful in all his fanatical jealousy, while others find him less appealing' (Rönnbäck 1945: 4). In the light of misconceptions and prejudices on the part of many people, the book provided a nuanced depiction of

12 It may be argued that the Swedish northern territories became more important strategically in view of the new borders after Sweden lost both Finland and later also Norway. 
Laestadius. Many of the Swedish publications on Laestadius and the revival from the first half of the twentieth century could be placed in a context that would counteract prejudice and discrimination. The same openness towards Laestadian issues in Finnish literature is found, for example, in books by Samuli Pauluharju, who wrote about Finnish migration to north Norway.

Bishop Johannes N. Skaar (18281904) of Tromsø was initially critical of Laestadianism, but gradually changed his view. On his visiting tours he met Sami people who reminded him of the importance of receiving a religious education in their own language. He thus came to disagree with the official policy of Norwegianization. The bishop sought to persuade the authorities to accept the use of the Sami and the Finnish languages, at least for Christian teaching in church and schools. He received little in the way of a response from the authorities, however, and so established the so-called 'FinneMisjonen' (later called Samemisjonen, the Sami mission), where he approved the use of minority languages and even of Laestadian preachers. ${ }^{13}$

This more open attitude regarding Laestadian followers, for whom Skaar had appointed himself spokesman, caused some priests to show greater interest in Laestadianism. The parish priest in Lyngen, Peter Cornelius Astrup (1887-1961), was initially mostly concerned with schooling and wanted to help the Sami pursue opportunities for education. Astrup's interest in schools led to closer contact with the Laestadians. He got in touch with their local leader, Erik Johnsen (1844-1941), wanting to learn more about the revival's history, its

13 This opening for collaboration with the Laestadians was retracted after Skaar's death. expansion and doctrines. This led to a close co-operation. The parish priest often visited Laestadian assemblies, resulting in the publication of a small volume of Laestadian sermons (Astrup 1924), as well as an account of the particular features of the Laestadians, as he characterized them, as a 'Sami form of Christianity' (Astrup 1928).

Astrup found the heart of the Sami form of Christianity in the ten theological beliefs that Erik Johnsen claimed were typical of the Lyngen Laestadians, contrary to what Laestadians claimed elsewhere. Astrup calls these beliefs 'national peculiarities', in the sense that they had come into being within a Sami environment as 'a response by people of nature to the protection of their culture, and what followed in its tracks' (Astrup 1928: 157). ${ }^{14}$ What Astrup particularly latched onto as 'Sami' was collectivist thinking. Contrary to Norwegians' individualistic way of thinking, Astrup believed that the Sami thought collectively: 'the individual becomes himself only along with others' (p. 157, author's italics).

In line with the scientific understanding of his time, Astrup expresses himself in cultural-essentialist categories. In order to understand a person's way of thinking, the strategies and courses of action of the group must first be understood. It is the fellowship that shapes humanity, and not the other way round. Astrup uses this understanding of fellowship to illustrate why Laestadian preachers always travelled around in pairs: the individual achieves nothing alone, but together they can cause the life of the soul to unfold and blossom. He thus found that one of the educational

14 Here, Astrup formulates an early version of 'the cultural protection hypothesis' (cf. Bjørklund 1985), in which Laestadianism serves as protection against unwanted external influences on local culture. 
features of the Laestadian understanding of salvation made great sense within a Sami cultural context: no-one can obtain salvation unless another person grants the remission of sins. The full value of an individual's religious status is something that is granted by the faith community. This understanding of salvation is expressed in a collectivistic mindset: the individual left sitting alone on the hull of a capsized boat cannot be saved because no-one can mediate the remission of their sins.

Although this way of thinking broke with a modern individualistic way of thinking, Astrup (1928: 157f.) argued that the Sami collectivistic mindset should be respected by the Norwegians for as long as the Sami people themselves sustained it within their own culture. In line with essentialist cultural understanding, every people's culture had the right to be respected just as it is even if it is in the process of changing, or even fading away. The Sami religious culture, their Sami form of Christianity, was therefore to be shown due respect by both society and the Church.

Astrup's account of Laestadianism is characterized by a deep sympathy for what he perceived as Sami elements that have been given a Christian form of expression. ${ }^{15} \mathrm{He}$ refers to Laestadius, but not in the negative manner of Hvoslef, Dahl, Englund or Heurgren before him. Astrup places emphasis on Laestadius's pietistic influence, which made him into a great penitential preacher; his experiences of meeting a Sami girl called Maria, who made him into a great pastor; and he shows how Laestadius's foremost disciple, Juhani

15 The priest Jens Otterbech expressed many of the same opinions in his book, Kulturverdier hos Norges finner (Cultural values among the Norwegian Finns [Sami], 1920).

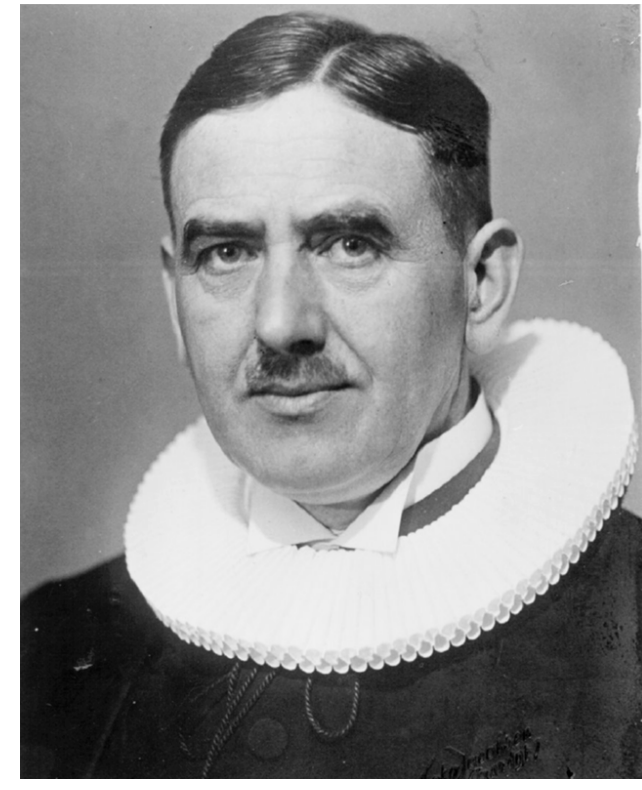

Priest Peter Cornelius Astrup (1887-1961). Nord-Troms Museum.

Raattamaa, managed to find an effective way of mediating words of grace to the penitent. For Astrup, Laestadianism is a form of Christianity that is well suited to the Sami way of being, in that it has been fashioned within a Sami milieu by the Sami. Even the Kautokeino uprising did not change Astrup's positive view of the Sami people's Laestadianism and he refused to let the revival take the blame for what happened in Kautokeino. Astrup also defends the Laestadians' pietism, though he is clear that even this form of Christianity may be biased and prone to misuse. He believed that their stern warnings against a dissolute life are effective protection against the dangers that often threaten any 'people of nature', and that these warnings can also be understood as a reaction against what is perceived as the harmful influence of Norwegian high culture. Between external temptation and internal lust there is, unlike in Norwegian culture, no individual will, but a collective consciousness 'that will fall alone, where it would never fall when 
several were gathered together, or so long as he does not break with the common consciousness' (Astrup 1928: 162).

Astrup's publication of Lyngen Laestadian sermons and his presentation of their characteristic features was later followed up on the Laestadian side. Two collections of sermons were published by the Lyngen Laestadians themselves, in 1929 and 1931. In addition, Astrup initiated a publication of an account by the Laestadian preacher Ananias Brune (1853-1942) about 'the living Christianity in Vadsø', along with Erik Johnsen's own account of the Laestadians' faith and doctrine in the Norvegia Sacra yearbook of 1934 (published in 1938). Johnsen's text may be said to represent a theological 'written programme' for the Lyngen Laestadians. The text has been included in all the later publications of Laestadian sermons published by Lyngen Lutheran-Laestadian congregations.

Brune and Johnsen's contributions in the Norvegia Sacra publications were the first occasion that the Laestadians themselves were included and presented as Laestadian actors to the Norwegian public. It was, however, not the first time that the Laestadians had approached the public. From the beginning of the revival, letters had been an important means of communication between the revival's leaders and the Laestadian congregations. Juhani Raattamaa was in contact with the congregations with the help of letters, also ably assisted by his co-worker, Mathilda Fogman. This correspondence literature was highly prized by the faithful and the letters circulated far and wide. They were eventually published in book form. The first collection came out in Finnish in 1898. In Swedish the first collection of letters was published in 1938 by Johan Pietiläinen, and translated into Norwegian the same year
(Børresen 1938). In 1966, the 1938 edition was republished (Antonsen 1966), with some minor omissions, but supplemented with some newer letters, as well as an article by Firstborn preacher Jens Pedersen about the spread of Laestadianism in Lofoten. ${ }^{16}$ His presentation was soon supplemented by a series of newspaper articles about the Laestadian revival in Ofoten, written by the Laestadian preacher Anton Karlsen (18801954). These articles were later published as a book (Karlsen 1986). Both Pedersen and Karlsen's accounts are important examples of how the Laestadians created their own historical narratives.

Laestadius himself never published his sermons, but written copies were nonetheless used by the revival's many preachers. The first printed sermon publication was in 1876 . This book was translated into Norwegian by Ananias Brune in 1901 (cf. Andreassen 2019). Some Finnish priests, such as Aatu Laitinen (1853-1923), worked as Laestadian preachers themselves. In 1918, Laitinen noted down his memories of early Laestadian Christianity in Lapland. Another Finnish Laestadian priest, Leonard P. Tapaninen (1893-1982) had a lecture published in 1924 on the history of the revival in the journal Siionin Lähetyslehti (Zion's mission magazine). In Norway, the dual roles of priest and Laestadian preacher were not combined as they were in Finland, ${ }^{17}$ but the Laestadians nonetheless had some talented speakers, including Ananias Brune, who collected material partly from Laestadius himself,

16 Pedersen's article was first published in Ola Berg's Buksnes bygdebok, vol. 1 (Bodø 1950).

17 There is presently no research as to why the two roles could not be combined in the Norwegian context. 
but also from Westeson and Tapaninen (Brune 1927).

Ananias Brune hailed from Sunnmøre and came as a teacher to eastern Finnmark in 1874. While in Finnmark he became familiar with the Finnish-speaking community and learned their language. While he was a teacher in Vadsø his conversion to Laestadianism became publicly known. As a Laestadian he soon came into conflict with Pastor Gjølme in Vadsø and was suspended from his post, but was later acquitted in the provost court. During the time of his suspension he began to translate Laestadius's sermons. After he moved to Hammerfest in 1921 , Brune became one of the main leaders of the Alta congregation (the so-called 'Small Firstborns'), and was asked to write an account about the history of the Vadsø Læstadians for the ecclesiastical yearbook, Norvegia Sacra (Brune 1938).

The occasion for Brune writing 'Nogle ord om Læstadius og loestadianismen (Some words on Laestadius and Laestadianism) in 1927 was three articles that appeared in the Church newspaper Nidaros in Trondheim, written by a former parish priest of Kautokeino. ${ }^{18}$ Here, Laestadius was depicted as a coarse and unruly doomsday prophet. When Brune was refused a right of reply in the newspaper to correct this depiction, he published his reply at his own cost. The articles in Nidaros are proof that the hostile depiction of Laestadianism as it had been communicated by Hvoslef, Dahl, Englund and Heurgren was still significant well into the twentieth century. The difference was that the Laestadians now had followers

18 The author is not mentioned, but it might have been Brage Høyem (b. 1874) from Trondheim who served in Kautokeino just after the turn of the century, or Thorfinn Solberg (1897-1982) who served there in the 1920 . who could write fluently in Norwegian and had a solid competence in providing alternative representations of how they wished to be presented.

As well as countering the articles' faultfinding and hostile criticism of Laestadianism as a 'race-based Christianity' (Brune 1927: 60), Brune reacted to the central position that the articles had ascribed to Laestadius as the founder of the movement. Brune believed that Laestadius could be better depicted with Raattamaa's words, that Laestadius was to be regarded as 'the first and best worker in this Christianity' (p. 5). Brune compared him to the famous Norwegian revival preacher, Hans Nielsen Hauge (1771-1824). He also criticized the article's author for his attempt to extrapolate Laestadius's character from his childhood experiences with an angry father and a melancholy mother, claiming that the author had overlooked the significance of Laestadius's account of his spiritual renewal in 1844. Brune also cited Laestadius's presentation of the memories of his childhood and youth, and believed that such memories provided a better impression of Laestadius than the bleak picture found in the article.

Brune's accounts are full of examples from both Laestadius's writings and from Westeson's accounts of how the revival's 'fire was lit' in the Lapland wilderness. $\mathrm{He}$ addresses what he considers to be erroneous representations in the Nidaros articles and tries to counter them with wellarticulated explanations. He tries not to be demagogic or malicious, but rather constructively apologetic by correcting misapprehensions. $\mathrm{He}$ maintains that the movement's ecstatic forms are not unique to Laestadianism, but expressions of internal sorrow or joy. They express the fact that it is in the nature of faith to have a subjective basis and the strength of the agitations 
comes from God according to an individual's needs, even though they do not have 'sacramental value and power' (Brune 1927: 52).

Brune was a voice from within the movement itself. As such he is - though in a different way from Astrup - a typical representative of the apologetic phase. While the author of the Nidaros article obviously had followed Astrup's lead in viewing Laestadianism as an expression of a Sami form of Christianity, Brune admits that such a characteristic seems alien to him (Brune 1927: 62). For Brune, Laestadianism is primarily the expression of Christian faith, regardless of whether the faithful are Sami, Kven or Norwegian. As a Laestadian himself, he had witnessed how the movement had become a unifying and transformative force in society - a source of what Kåre Svebak many years later called a 'religiousethnic fellowship' that transcended ethnic divisions (Svebak 1983).

Although the critical attitude towards Laestadianism during the first period was gradually replaced over the course of the twentieth century by a more open and welldisposed attitude, many of the negative attitudes were still hanging around well into the century. An example of this is the book by Carl Hasselberg (1856-1938) about the church history of Tornedalen (Hasselberg 1935). In this book Hasselberg followed the older critical view of Laestadianism, focusing on Lars Levi Laestadius as a person as a basis for understanding Laestadianism as a revival movement.

In his review of Laestadianism, Hasselberg looks at conceptions of the movement in the light of Church theology. He particularly focuses on penitence, congregational understanding, the word of grace and agitation. He claims that Laestadian 'special meanings' are not deviations from the Church's faith, but rather to be understood as religious innovations. The problem with innovations, however, is that they often emphasize doctrinal points, systems or practices that for a while have been underemphasized or overlooked (Hasselberg 1935: 245), so that when they are brought forth again they become over-emphasized. $\mathrm{He}$ acknowledges that Laestadianism has fulfilled an important function among the northern peoples and says that it
seems to be the form of Christianity that is best suited to the spiritual tem- perament of this population, the one that with regard to its particular char- acteristics in terms of the people's psy- chology is most appropriate for bring- ing Christianity into their hearts. This is especially true of the Lappish [Sami] population, who have found fulfilment here of their religious needs. (Hasselberg 1935: 306, author's translation)

One contrast to Hasselberg's 'popular psychological' approach to Laestadianism is evident in the thesis by Aulis Zidbäck (1900-90) from Kuopio, Finland. Zidbäck (1937) tries to understand Laestadianism in the light of church history in general and relates Laestadius's theological ideas to medieval Catholic mysticism (cf. Boreman 1954: 196, 201). Zidbäck thus avoids cultural essentialism and rather links Laestadianism to general currents within European ecclesiastical traditions. In this way Laestadianism is not understood as 'deviation' from something that is 'normal' or 'right', but as an example of a tradition of piety in European ecclesiastical history, albeit one with individual and unusual features. He thus contributes to the legitimizing of the Laestadian interpretation of Christianity. His decision to relate Laestadian pietistic mysticism to its 
medieval counterpart was original, but was not always well received in the field of ecclesiastical history; his points of view were criticized by, for example, Martti Miettinen (1942), and later by Per Boreman (1954). At the same time, it should be noted that it was precisely researchers such as Zidbäck and Miettinen who, in different ways, led Laestadianism research out of the cultural essentialism epoch and into the era of church history. In Sweden the emerging field of Laestadianism research was characterized by scholars such as Per Boreman, and in Norway by Dagmar Sivertsen (1955). This change of direction in ecclesiastical history was later perpetuated by social scientists who focused on the revival's function in relation to society, culture and ethnicity, rather than viewing Laestadianism in an ecclesiastical historical context.

\section{Conclusion}

Early Norwegian commentators on the Laestadian revival were heavily influenced by the 1852 events in Kautokeino. These events contributed to giving the religious revival a negative reputation, both within and outside the church. In society at large, religious revivals were for a long time considered not only in terms of religious excesses, but also as a result of madness and insanity. ${ }^{19}$ Laestadianism as an aberration from 'normal' religious practice dominated the scene well into the twentieth century.

An important change, however, took place early in the twentieth century, probably for several reasons. In Sweden there seems to have been a greater concern about the northern territories, resulting in articles and books about northern culture. The more liberal minded in the national

19 Cf. Astri Andresen's article on changing perceptions of insanity among the Sami (Andresen 2007). church, both in Sweden and in Norway, thus took a greater interest in the cultural aspect of the northern culture. This interest gave writers the opportunity to highlight those aspects of northern religious culture that were different from the mainstream national culture, thus resulting in publications that focused on Laestadian religious and cultural beliefs and practices.

In Norway, the so-called 'Norwegianization policy' towards the Sami and the Kven were strictly enforced throughout the latter part of the nineteenth century and for a long time afterwards. Several members of the clergy - and even some Norwegian bishops - were critical of this process. The Lyngen clergyman, Peter C. Astrup, even attempted to ground his respect for the Sami in the dominant scientific view of culture in his time, cultural essentialism. In his view, Laestadianism was portrayed as the main form of Christianity, especially adapted to the Sami collectivistic mindset as a special form of Christianity, a 'Sami Christianity'.

Towards the middle of the twentieth century, this more appreciative understanding of Laestadianism, began to attract the attention especially of church historians. New research and interpretations of Laestadianism were attempted, first in Finland, but later also in Sweden and in Norway. Social scientists and anthropologists later followed other research paradigms, focusing on ways in which Laestadianism could be interpreted to have had unique functions in relation to society. This trend opened up much new research on the Laestadian movement, especially from the 1960 s and onwards. 


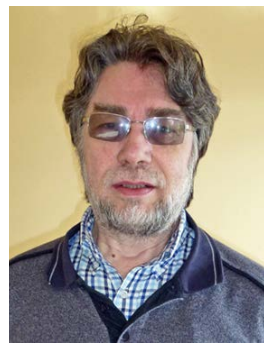

Roald E. Kristiansen, is an associate professor at the Department of Archeology, History, Religious Studies and Theology in UiT The Arctic University of Norway since 1997. He has an MA from Oslo University in theology (1979), and a PhD from Emory University in Atlanta, Georgia, USA, in constructive theology with a thesis on interfaith dialogue and theology (1987). He has been a visiting scholar at the National Council of Churches' study centre in Kyoto, Japan (1985/6), a seminary lecturer at the Methodist School of Theology in Bergen (1980-91), and associate professor at Finnmark University College (19917). Roald Kristiansen has published on interfaith theology, ecotheology, and contextual theology, as well as on Buddhism and Confucianism.

\section{List of references}

Ahrenberg, Jakob, 1897 (1889). Skildringar från Östre Finland (Stockholm, Albert Bonnier)

Andreassen, Bengt-Ove, 2019. 'Taler i trykk. Bokhistoriske perspektiver på utgivelser av Læstadius' taler', in Din. Tidsskrift for religion og kultur, 1, pp. 7-33

Andresen, Astri, 2007. 'In the wake of the Kautokeino event: changing perceptions of insanity and the Sámi 1852-1965', in Acta Borealia, 24(2), pp. 130-42, doi: <https:// doi.org/10.1080/08003830701661746>

Antonsen, Bertheus, 1966. Brevboken av 1966. Skrifter og brever fra kristendommens eldste og predikanter m.fl. i vårt tidsrum (Beisfjord in Ofoten, Bertheus Antonsen)

Astrup, Peter Cornelius, 1924. Loestadianske taler nedtegnet paa Skibotn marked høsten 1923 (Tromsø, Bjerrings Bok- \& Akcidenstrykkeri)

-_-1928. 'Læstadianismens særpreg', in Norvegia Sacra 1928, pp. 155-64 (Kristiania, Steenske forlag)

Barth, Fredrik, 1969. Ethnic Groups and Boundaries: The Social Organization of Culture Difference (Oslo, Universitetsforlaget)

Bjørklund, Ivar, 1985. Fjorfolket i Kvænangen: Fra samisk samfunn til norsk utkant 15501980 (Oslo, Universitetsforlaget)

Boreman, Per, 1954 (1953). Loestadianismen. Fännoskandiens märkligaste väckelse och dess förhållande till kyrkan, 2nd revised edn (Stockholm, Svenska kyrkans diakonistyrelse)

Boreman, Per, and Gustaf Dahlbäck (eds.), 1965. Lars Levi Loestadius och hans gärning. Festskrift till hundraårsminnet av hans död den 21 februari 1861 (Stockholm, Svenska kyrkans diakonistyrelses bokförlag)

Børresen, Andreas, 1938. Brevboken av 1938. Skrifter og brever fra kristendommens eldste og predikanter m.fl. i vårt tudsrum, samt nogen minnetaler (Bergen, Daniel Josefsen of Holandshamn \& Jens Pedersen of Balstad)

Brune, Ananias, 1927. Nogen ord om Loestadius og loestadianismen (Hammerfest)

_——1938. 'Den levende kristendom i Vadsø. Den såkalte læstadianske menighet i Vadsø', in Norvegia Sacra 1934, pp. 41-85 (Oslo, Steenske forlag)

Curtelius, Elisabeth, 1914. Lars Levi Lostadius: en nykterhetskämpe i höga Norden (Uppsala, Lindblad)

Dahl, Ludvig. 1859. Bidrag til Kundskab om de Sindssyge i Norge (Christiania, Steenske Bogtrykkeri)

- - 1862. 'Om nogle aandelige Omgangssygdomme', in Folkevennen, 11, pp. 1-99 (offprint)

Edquist, Märta, 1921. Den gamla kyrkbyn. Berättelser från Lappmarken (Stockholm, Svenska kyrkans diakonistyrelse)

-_-1922. Lars Levi Loestadius. En kulturbild från den stora väckelsen $i$ Tornedalen (Uddevalla, Svenska kyrkans diakonistyrelse)

Englund, Jacob A., 1876. 'Lars Levi Læstadius: en kyrklig tidsbild', in Teologisk Tidskrift, 16, pp. 24-44

- - 1881. 'Lars Levi Læstadii dogmatiska åsigter', in Teologisk Tidskrift, 21, pp. 435-65

Grene, Gudrun Tokle, and Anne Helene Kvelm Lie, 2018. 'Å synge salmer i visetakt', in Tidsskrift for Den Norske Legeforening, 18(20), pp. 1-9, doi: <https://doi. org/10.4045/tidsskr.18.0129>

Hanssen, Svein, 1994. Sørreisa bygdebok. Gård og slekt, bind 1 (Sørreisa kommune)

Hasselberg, Carl J., 1935. Under Polstjärnan. Tornedalen och dess kyrkliga historia (Uppsala, J.A. Lindblads förlag)

Hedlund, Anders (ed.), 1889. Ett försök at nio prestmän och biskop L. Landgren att 
reformera den Loestadianska läran och andeliga rörelsen $i$ Norrbotten och Finland (Luleå, Luleå Boktryckeri)

Heurgren, Paul, 1916. Lars Lewi Lostadius: en religiös fanatiker $i$ Torne Lappmark vid början och midten af förra århundradet: föredrag i sällskapet Concordia den 17 mars 1916 (Örebro dagblads tryckeri)

Hvoslef, F. W., 1857. 'Noget om den religiøse Bevegelse i Kautokeino', in Theologisk tidsskrift for den norske kirke, 7, pp. 1-38

Johansson, Gustaf, 1898. Den närvarande loestadianismens läroframställning (Luleå, Bergmans bokhandel)

Johnsen, Erik. 1938. 'Læstadianernes tro og lære. En redegjørelse fra læstadianske predikanter i Troms fylke, dat. Skibotn i februar 1932', in Norvegia Sacra. Aarbok til kunnskap om Den norske kirke i fortid og samtid 1934, pp. 86-92 (Oslo, Steenske forlag)

Karlsen, Anton, 1986. Den loestadianske bevegelses historie $i$ Ofoten og Lofoten (Beisfjord in Ofoten, Alvin Nystad)

Kristiansen, Roald E., 2004. 'Fra noaidens datter til de kristnes mor. Om læstadianismens fremvekst i Sør-Troms og Ofoten', in Ett land, ett folk. Sápmi $i$ historia och nutid, eds. Per Axelsson and Peter Sköld (CESAM, Umeå Universitet), pp. 85-100

Læstadius, Lars Levi, 1979. Tidskriften Ens ropandes röst $i$ öknen: åren 1852-54 (Bromma, S.W. Wettainen)

- - 1997. Dårhushjonet: en blick $i$ nådens ordning. Systematiskt framställd under form af betracktelser öfwer själens egenskaper och tillstånd (Skellefteå, Artos)

Lindholm, Valdemar, 1937. Som örnar över vidderna. Några bilder från bröderna Lars Levi och Petrus Lostadii ungdomsår (Stockholm, Svenska Missionsförbundets förlag)

Miettinen, Martti E., 1942. Lestadiolainen herätysliike, vol. 1, Perustajan aika (Helsinki, Otava)

Otterbech, Jens, 1920. Kulturverdier hos Norges finner (Kristiania, Aschehoug)

Pietiläinen, Johan (ed.), 1938. Brevsamling av 1938 (Luleå, Johan Pietiläinen)

Rönnbäck, Oscar, 1945. Ödemarkens apostel. Berättelse om Lars Levi Loestadius' liv och gärning (Stockholm, Harrier)

Shurmer-Smith, Pamela, 2001. Doing Cultural Geography (London, Sage)
Sivertsen, Dagmar, 1955. Lostadianismen $i$ Norge (Oslo, Land og kirke)

Svebak, Kåre, 1983. 'Religiøs etnisitet: forbrødning og etnisk mangfold i lestadianske tradisjoner', in Folk og ressurser i nord, ed. Jørn Sandnes et al. (Trondheim, Tapir), pp. 259-76

Tapaninen, Leonard P., 1924. 'Peräpohjolan herännäisyys', in Siionin Lähetyslehti, 7, pp. 106-11

Westeson, Hjalmar, 1922. Ödemarksprofetens lärjungar (Stockholm, Svenska kyrkans diakonistyrelses bokförlag, reprinted 1930 and 1980)

Zidbäck, Aulis, 1937. Lars Levi Laestadiuksen kristillisyyden-näkemys. Erityisesti silmälläpitäen Kristuksen seuraamisen ihannetta, doctoral thesis (University of Helsinki) 